\title{
Xanthines as a scaffold for molecular diversity
}

\author{
Gerhard Heizmann and Alex N. Eberle* \\ Laboratory of Endocrinology, Department of Research (ZLF), University Hospital and University Children's Hospital Basel, \\ CH-4031 Basel, Switzerland
}

Received 6 December 1996

Accepted 6 February 1997

Keywords: Xanthines; Combinatorial chemistry; Diversity; Small molecules

\begin{abstract}
Summary
Xanthines represent a new, versatile scaffold for combinatorial chemistry. A five-step solid-phase synthesis of xanthine derivatives is described which includes alkylations, a nucleophilic displacement reaction at a heterocycle and a ring closure reaction by condensation of a nitroso function with an activated methylene group. The selected reaction sequence allows the production of a highly diverse small-molecule combinatorial compound library.
\end{abstract}

\section{Introduction}

Combinatorial compound libraries represent a powerful method to identify new pharmaceutical lead compounds for a given biological target [1]. One of the challenges in generating new kinds of libraries is the development of scaffolds that allow the introduction of a maximum of diversity. Recent investigations showed the successful synthesis on a solid support of several small molecules that are suitable as scaffolds for the generation of molecular diversity [2]. The application of solid-phase technology to the preparation of such new scaffolds for combinatorial chemistry requires the transfer of solution-phase chemistry to conditions that are feasible on the solid support. The reactions should proceed in resin-swelling solvents and the reaction temperatures should be kept at reasonable values.

Xanthines represent a new structurally rigid scaffold for combinatorial chemistry. Certain naturally occurring xanthines (e.g. caffeine, theophylline and theobromine) are well known to exert prominent physiological effects at very low doses, and they have been used as pharmaceuticals, narcotics or stimulants for many centuries [3]. Today, 8-substituted xanthines are studied extensively for clinical application [4], as they inhibit many pharmacological and physiological effects of adenosine [5]. In order to use the xanthine scaffold for combinatorial chemistry, we have developed a method of solid-phase synthesis of highly substitutable xanthines for the generation of new compound libraries.

\section{Results and Discussion}

The ring closure reaction of 1,3-dialkyl-6-alkylamino-5nitrosouracils 1 proceeds easily, giving the corresponding xanthine derivatives $\mathbf{2}$, as long as $\mathrm{N1}$ is blocked by a substituent (Scheme 1) [6].

The application of solid-phase technology to the generation of combinatorial compound libraries necessitates the adaptation of this reaction to solid-phase conditions. As a first step, we coupled bromoacetic acid to the free amino function of a solid support 3, which is modified by the Rink amide linker [7]. We used the Rink linker because of its stability towards a wide variety of reaction conditions. 1-Alkyl-4-chlorouracils 5 were then attached to the solid phase by alkylation of the nitrogen at the uracil system to form intermediates 6 . The chlorine of the resinbound uracils 6 can easily be replaced by primary benzylamines to form 4-benzylaminouracils 7 .

The intermediates 7, bound to the solid support, were treated with isopentyl nitrite in the presence of a small amount of acetic acid. The nitroso compounds formed first immediately undergo ring closure to form the xanthine derivatives 8 . This conversion could be followed by UV spectroscopy, since the absorption band at 260-265 $\mathrm{nm}$, characteristic for the uracil-type compounds 7, disap-

*To whom correspondence should be addressed. 
<smiles>[2H]CNc1c([N+](=O)[O-])c(=O)n([12CH])c(=O)n1P</smiles>

1<smiles>[R8]c1nc2c([nH]1)c(=O)n([2H])c(=O)n2[2H]</smiles>

2

Scheme 1. Formation of xanthine derivatives 2 by ring closure of 1,3-dialkyl-6-alkylamino-5-nitrosouracils $\mathbf{1}$. Note that N1 is blocked.

peared and was shifted to $306-310 \mathrm{~nm}$, characteristic for xanthines $\mathbf{8}$. The progress of all reactions was judged by cleavage of a small amount of the reaction product from the solid phase, followed by analysis by UV spectroscopy and comparison of HPLC characteristics of the product with those of product prepared in solution (if available). Alkylation of these compounds proceeded with excess alkylating agent in the presence of triethylamine to give

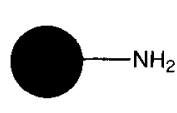

3

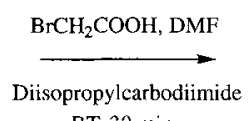

RT; 30 min<smiles>O=C(CBr)NC1CCCCC1</smiles><smiles>O=c1cc(Cl)[nH]c(=O)n1Br</smiles>

5<smiles>[R]c1ccccc1CNc1cc(=O)n([R1])c(=O)n1CC(=O)NC1CCCCC1</smiles>

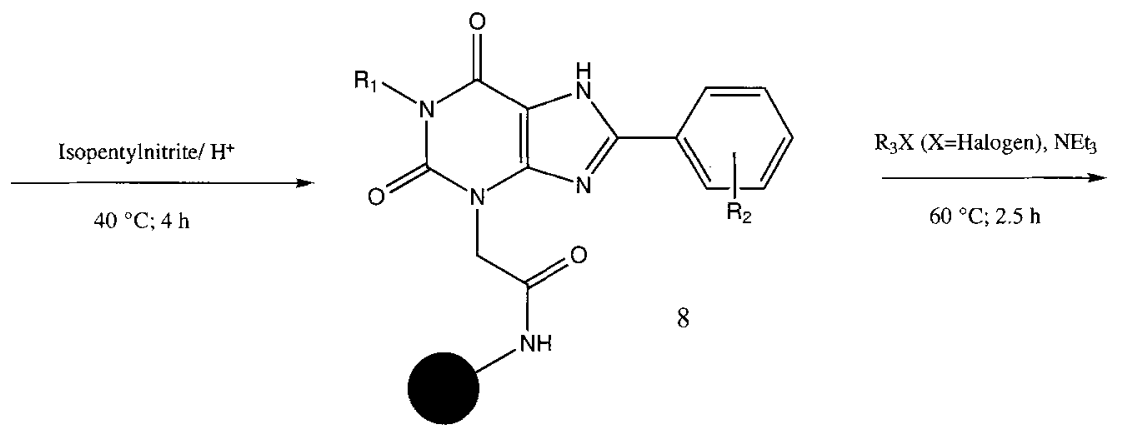<smiles>[R]c1ccccc1-c1nc2c(c(=O)n([R])c(=O)n2CC(=O)NC2CCCCC2)n1[R8]</smiles><smiles>[R2]c1ccccc1-c1nc2c(c(=O)n(C)c(=O)n2CC(N)=O)n1[B]</smiles>

Fig. 1. Solid-phase synthesis of fully substituted xanthines. 
TABLE 1

\begin{tabular}{|c|c|c|c|c|c|c|c|}
\hline No. & $\mathbf{R}_{1}$ & $\mathrm{R}_{2}$ & $\mathrm{R}_{3}$ & $\mathbf{R}_{4}$ & Yield $^{a}(\mathrm{mg})$ & $\begin{array}{l}\text { Retention time } \\
\text { (min) (see text) }\end{array}$ & $\begin{array}{l}\text { MW (g/mol) } \\
\text { MS }\left(\mathrm{MH}^{+}\right)^{\mathrm{b}}\end{array}$ \\
\hline $10 a$ & $\mathrm{CH}_{3}$ & & & $2^{\prime}-\mathrm{OCH}_{3}$ & $1.94(10 \%)$ & 10.87 & $\begin{array}{l}367.37 \\
368.1\end{array}$ \\
\hline $10 \mathrm{~b}$ & & & & $4^{\prime}-\mathrm{CF}_{3}$ & $3.63(14 \%)$ & 13.06 & $\begin{array}{l}500.44 \\
502.2\end{array}$ \\
\hline $10 \mathrm{c}$ & $\mathrm{CH}_{3}$ & & $\mathrm{H}$ & 4'-F & $1.80(19 \%)$ & 8.75 & $\begin{array}{l}317.28 \\
320.4\end{array}$ \\
\hline $10 \mathrm{~d}$ & $\mathrm{CH}_{3}$ & & & $4^{\prime}-\mathrm{F}$ & $3.55(32 \%)$ & 6.57 & $\begin{array}{l}374.33 \\
377.2\end{array}$ \\
\hline $10 \mathrm{e}$ & $\mathrm{CH}_{3}$ & & $\mathrm{H}$ & $4^{\prime}-\mathrm{CH}_{3}$ & $2.34(25 \%)$ & 9.45 & $\begin{array}{l}313.32^{\mathrm{c}} \\
314.5\end{array}$ \\
\hline $10 f$ & $\mathrm{CH}_{3}$ & & & $4^{t}-\mathrm{CH}_{3}$ & $3.56(32 \%)$ & 7.46 & $\begin{array}{l}370.37^{\mathrm{c}} \\
371.4\end{array}$ \\
\hline $10 \mathrm{~g}$ & $\mathrm{CH}_{2} \mathrm{CH}_{2} \mathrm{CH}_{3}$ & & $\mathrm{H}$ & $4^{\prime}-F$ & $2.42(23 \%)$ & 10.60 & $\begin{array}{l}345.33 \\
344.1\end{array}$ \\
\hline $10 \mathrm{~h}$ & $\mathrm{CH}_{2} \mathrm{CH}_{2} \mathrm{CH}_{3}$ & & & $4^{\prime}-F$ & $3.10(26 \%)$ & 8.20 & $\begin{array}{l}402.38 \\
403.6\end{array}$ \\
\hline $10 \mathrm{i}$ & $\mathrm{CH}_{2} \mathrm{CH}_{2} \mathrm{CH}_{3}$ & & $\mathrm{H}$ & $4^{\prime}-\mathrm{CH}_{3}$ & $1.31(13 \%)$ & 11.23 & $\begin{array}{l}341.37 \\
342.4\end{array}$ \\
\hline $10 \mathrm{j}$ & $\mathrm{CH}_{2} \mathrm{CH}_{2} \mathrm{CH}_{3}$ & & & 4'- $-\mathrm{CH}_{3}$ & $1.52(11 \%)$ & 8.98 & $\begin{array}{l}398.42 \\
400.5\end{array}$ \\
\hline
\end{tabular}

a The yield after RP-HPLC purification (based on a resin loading of $0.23 \mathrm{mmol} / \mathrm{g}$ ) reflects the recovery of pure product. Analysis by RP-HPLC of the crude products (after cleavage from the resin) showed purities indicated by peak areas ranging from $86-98 \%(\lambda=300 \mathrm{~nm})$ of $65-89 \%(\lambda=$ $220 \mathrm{~nm}$ ).

${ }^{b}$ Mass spectrometric data were obtained on a MALDI system (Linear Scientific 1700, Reno, CA, U.S.A.).

${ }^{\circ}$ For NMR data see text.

the fully substituted xanthines $\mathbf{9}$. The final products $\mathbf{1 0}$ were cleaved from the solid support by the action of trifluoroacetic acid. The cleavage procedure was as follows. The resin was treated twice with $95 \%$ trifluoroacetic acid and washed with $95 \%$ trifluoroacetic acid, dichloromethane and trifluoroethanol. The combined solvents were removed over potassium hydroxide in an evacuated desiccator, after which the residues were lyophilized twice from dilute acetic acid and directly purified by HPLC.
Analytical and preparative HPLC was performed on a Jasco system (Tokyo, Japan). Analytical runs were carried out on a Waters Symmetry $\mathrm{C}_{18}$ column $(3.9 \times 150 \mathrm{~mm})$ using a linear solvent gradient from $5 \%$ to $100 \%$ solvent $\mathrm{B}$ in 20 min (solvent $\mathrm{A}=0.1 \%$ TFA in water; solvent $\mathrm{B}=$ $0.1 \%$ TFA in acetonitrile/water, 7:3). Preparative runs were carried out on a Waters Symmetry $\mathrm{C}_{18}$ column (19 $\times 150 \mathrm{~mm}$ ) with a linear solvent gradient from $25 \%$ to $60 \%$ solvent $\mathrm{B}$ in $22 \mathrm{~min}$. 
We investigated the applicability of this method by first synthesizing two individual xanthines (10a and 10b). The potential of the synthetic scheme to produce combinatorial compound libraries was then determined by the synthesis of a group of eight related xanthines $(\mathbf{1 0 c}-\mathbf{1 0 j})$. The original amount of resin was continuously divided into smaller portions along with the progressing reaction sequence (see Fig. 1). In this way, eight individual xanthines were obtained by cleavage from the eight different resin portions. The analytical data of these compounds are summarized in Table 1. The structure of two compounds (10e and 10f) was verified by NMR spectroscopy. NMR spectra were recorded on a Bruker $300 \mathrm{MHz}$ instrument. NMR data of compound 10e: ${ }^{1} \mathrm{H}$ NMR (DMSO- $\left.d_{6}, \mathrm{ppm}\right): 7.53 \mathrm{~d}(2 \mathrm{H}), 7.36 \mathrm{~d}(2 \mathrm{H}) \mathrm{ArH} ; 4.58 \mathrm{~s}$ (2H) $\mathrm{CH}_{2} \mathrm{CO} ; 3.30 \mathrm{~s}(3 \mathrm{H}) \mathrm{N}-\mathrm{CH}_{3} ; 2.38 \mathrm{~s}(3 \mathrm{H}) p-\mathrm{CH}_{3}$. NMR data of compound 10f: ${ }^{1} \mathrm{H}$ NMR (DMSO- $d_{6}, \mathrm{ppm}$ ): $7.67 \mathrm{~d}(2 \mathrm{H}) \mathrm{CO}-\mathrm{NH}_{2} ; 7.53 \mathrm{~d}(2 \mathrm{H}), 7.36 \mathrm{~d}(2 \mathrm{H}) \mathrm{ArH} ; 7.28$ d $(2 \mathrm{H}) \mathrm{CO}-\mathrm{NH}_{2} ; 4.94 \mathrm{~s}(2 \mathrm{H}) \mathrm{CH}_{2} \mathrm{CO} ; 4.57 \mathrm{~s}(2 \mathrm{H})$ $\mathrm{CH}_{2} \mathrm{CO} ; 3.28 \mathrm{~s}(3 \mathrm{H}) \mathrm{N}-\mathrm{CH}_{3} ; 2.38 \mathrm{~s}(3 \mathrm{H}) p-\mathrm{CH}_{3}$.

\section{Conclusions}

We have demonstrated the successful transfer of solution-phase reactions to a solid-phase synthesis of xanthine derivatives. The applicability of this synthetic strategy for the generation of molecular diversity was tested with the preparation of a small xanthine library consisting of eight individual entities. The method can easily be extended to generate libraries with a large number of compounds. A library containing 90 individual compounds was prepared in this way and is currently being tested in various biological assays.

\section{Acknowledgements}

We thank Dr. R. Andreatta, Dr. A. Marzinzik and Mr. H. Müller, Ciba-Geigy AG, Basel, Switzerland for carrying out the mass spectrometric and NMR analyses. G.H. was supported by the DF fund.

\section{References}

1 a. Houghten, R.A., Combinatorial libraries. Finding the needle in the haystack, Curr. Biol., 4 (1994) 564-567.

b. Eichler, J., Appel, J.R., Blondelle, S.E., Dooley, C.T., Dorner, B., Ostresh, J.M., Perez-Paya, E., Pinilla, C. and Houghten, R.A., Peptide, peptidomimetic, and organic synthetic combinatorial libraries, Med. Res. Rev., 15 (1995) 481-496.

c. Gallop, M.A., Barrett, R.W., Dower, W.J., Fodor, S.P.A. and Gordon, E.M., Applications of combinatorial technologies to drug discovery. 1. Background and peptide combinatorial libraries, J. Med. Chem., 37 (1994) 1233-1251. d. Gordon, E.M., Barrett, R.W., Dower, W.J., Fodor, S.P.A. and Gallop, M.A., Applications of combinatorial technologies to drug discovery. 2. Combinatorial organic synthesis, library screening strategies, and future directions, J. Med. Chem., 37 (1994) 13851401.

e. Felder, E.R., The challenge of preparing and testing combinatorial compound libraries in the fast lane, at the front edge of drug development, Chimia, 48 (1994) 531-541.

f. Terrett, N.K., Gardner, M., Gordon, D.W., Kobylecki, R.J. and Steele, J., Combinatorial synthesis: The design of compound libraries and their application to drug discovery, Tetrahedron, 51 (1995) 8135-8173.

2 a. Bunin, B.A. and Ellman, J.A., A general and expedient method for the solid phase synthesis of 1,4-benzodiazepine derivatives, $\mathbf{J}$. Am. Chem. Soc., 114 (1992) 10997-10998.

b. DeWitt, S.H., Kiely, J.S., Stankovic, C.J., Schroeder, M.C., Cody, D.M.R. and Pavia, M.R., 'Diversomers': An approach to nonpeptide nonoligomeric chemical diversity, Proc. Natl. Acad. Sci. USA, 90 (1993) 6909-6913.

c. Goff, D.A. and Zuckermann, R.N., Solid-phase synthesis of highly substituted peptoid 1 $(2 H)$-isoquinolinones, J. Org. Chem., 60 (1995) 5748-5749.

d. Patek, M., Drake, B. and Lebl, M., Solid-phase synthesis of 'small' organic molecules based on thiazolidine scaffold, Tetrahedron Lett., 36 (1995) 2227-2230.

e. Marzinzik, A.L. and Felder, E.R., Solid support synthesis of highly functionalized pyrazoles and isoxazoles; scaffolds for molecular diversity, Tetrahedron Lett., 37 (1996) 1003-1006.

f. MacDonald, A.A., DeWitt, S.H., Hogan, E.M. and Ramage, R.A., Solid phase approach to quinolones using the Diversomer technology, Tetrahedron Lett., 37 (1996) 4815-4818.

g. Dressman, B.A., Spangle, L.A. and Kaldor, S.W., Solid phase synthesis of hydantoins using a carbamate linker and a novel cyclization/cleavage step, Tetrahedron Lett., 37 (1996) 937-940.

h. Ruhland, B., Bhandari, A., Gordon, E.M. and Gallop, M.A., Solid-supported combinatorial synthesis of structurally diverse $\beta$ lactams, J. Am. Chem. Soc., 118 (1996) 253-254.

3 Mutschler, E. (Ed.), Arzneimittel-Wirkungen, Wissenschaftliche Verlagsgesellschaft, Stuttgart, Germany, 1986.

4 Hock, F.J., Therapeutic approaches for memory impairments, Behav. Brain Res., 66 (1995) 143-150.

5 a. Daly, J.W., Hide, I., Müller, C.E. and Shamim, M., Caffeine analogs: Structure-activity relationship at adenosine receptors, Pharmacology, 42 (1991) 309-321.

b. Olah, M.E. and Stiles, G.L., Adenosine receptor subtypes: Characterization and therapeutic regulation, Annu. Rev. Pharmacol. Toxicol., 35 (1995) 581-606.

6 a. Goldner, H., Dietz, G. and Carstens, E., Die Oxydation von 5 Nitrosouracilen, Liebigs Ann. Chem., 699 (1966) 145-152, and references cited therein.

b. Fuchs, H., Gottlieb, M. and Pfleiderer, W., Über die Cyclisierung von 4-Alkylamino-5-nitrosouracilen und die Synthese von 8substituierten Xanthinen und Bis(theophyllin-8-yl)alkan-Derivaten, Chem. Ber., 111 (1978) 982-995.

7 Rink, H., Solid-phase synthesis of protected peptide fragments using a trialkyloxy-diphenyl-methylester resin, Tetrahedron Lett., 28 (1987) 3787-3790. 